This item was submitted to Loughborough's Research Repository by the author.

Items in Figshare are protected by copyright, with all rights reserved, unless otherwise indicated.

\title{
Thermal conditions measurement
}

PLEASE CITE THE PUBLISHED VERSION

http://www.crcpress.com/product/isbn/9780415287005

PUBLISHER

(c) CRC Press

VERSION

AM (Accepted Manuscript)

LICENCE

CC BY-NC-ND 4.0

REPOSITORY RECORD

Havenith, George. 2019. "Thermal Conditions Measurement”. figshare. https://hdl.handle.net/2134/16764. 
Dr. George Havenith,

Human Thermal Environments Laboratory

Dept. Human Sciences

Loughborough University

Leics. LE11 3TU

United Kingdom

Tel +44 1509223031

Fax +44 1509223940

G.Havenith@lboro.ac.uk

\section{HANDBOOK OF HUMAN FACTORS AND ERGONOMICS METHODS}

General Editor: Professor Neville Stanton

Publisher: Taylor and Francis

\section{CHAPTER 60}

METHOD: THERMAL CONDITIONS MEASUREMENT

Dr. George Havenith,

Human Thermal Environments Laboratory

Dept. Human Sciences

Loughborough University

Leics. LE11 3TU

United Kingdom

Tel +44 1509223031

Fax+441509223940

G.Havenith@lboro.ac.uk 


\section{Background and application}

Thermal comfort and strain can be assessed by objective assessment of the heat exchange processes, and by subjective methods.

\subsection{Heat exchange processes}

This requires measurement of the climatic parameters affecting the human heat balance (Fig. 1). For comfort, or low thermal strain this balance should be close to equilibrium (heat production equals heat loss), resulting in a relatively stable body temperature.

Heat production is determined by metabolic activity. When at rest, this is the amount of energy needed for the body's basic functions. When working, the metabolic activity increases. When active muscles burn nutrients for mechanical activity, some energy is liberated outside the body as external work, but most energy is released internally as heat. The ratio between this external work and the total energy consumed is called the efficiency with which the body performs the work. Efficiency is close to zero for most tasks. In the cold, shivering can produce additional heat: muscle activity with zero efficiency, increasing metabolic rate and heat production up to fourfold.

Several pathways are available for heat loss, expressed in W.m ${ }^{-2}$, from the body, between skin and environment (Fig. 2). For each pathway the amount of transferred heat depends on the driving force (e.g. temperature or vapour pressure gradient), the body surface area involved and the resistance to that heat flow (e.g. clothing insulation).

Of the pathways shown in Fig. 2, unless working in water, in special gas mixtures (prolonged deep-sea dives), handling cold products or in supine positions, conductivity is not a relevant factor. Convection heat loss occurs when air cooler than the skin flows along the skin, and carries away body heat.

When there is a difference between the body's surface temperature and the temperature of the surfaces in the environment, heat will be exchanged by radiation. Finally, heat can be lost by evaporation of moisture (sweat) on the skin. Evaporative and convective heat losses also occur in the lungs during respiration, as inspired air is usually cooler and dryer than the lung's internal surface. This can be up to $10 \%$ of the total heat production.

The body gains heat when air temperature, radiant temperature or vapour pressure around the body is higher than the skin value, and this can result in heat stress. 


\subsubsection{Measurement of relevant factors in heat exchange}

External parameters that need to be assessed to determine heat or cold stress levels or comfort conditions include:

\section{Temperature}

As temperature increases body heat loss by convection, conduction and radiation decreases. Three relevant temperatures need to be assessed:

- Air temperature $\left(t_{a}\right)$. This can be measured by a conventional alcohol filled thermometer or by an electronic thermometer. Smaller sensors react faster to variations in the climate. Use a shielded sensor (Fig. 3) when radiation is present (sun or other heat source) Typically a (polished) shield is used in combination with a device to suck air (blowing could add heat from the fan motor) over the sensor to ensure a true air temperature measurement (see Assman psychrometer, Fig. 5). Sensor range/accuracy: to measure comfort: $10-40^{\circ} \mathrm{C} / \pm 0.5^{\circ} \mathrm{C}$; to measure stress $-40-+120^{\circ} \mathrm{C} /$ outside comfort range $\pm 1^{\circ} \mathrm{C}$; desirable accuracy $0.2^{\circ} \mathrm{C}$.

- Mean Radiant temperature $\left(\overline{t_{r}}\right)$. This is the mean temperature of all walls and objects in the space (including sky outdoors). When mean radiant temperature exceeds skin temperature (e.g. in steel mills, or in work in the sun) heat transfers from the environment to the skin. $\bar{t}_{r}$ is most commonly measured indirectly using a matt black globe (typically $15 \mathrm{~cm}$ diameter) with a temperature sensor in its centre (Fig. 4). Given the size of the globe, it needs a long period to equilibrate (>20 min), and is therefore not sensitive to fast fluctuations in radiation. The globe temperature can be used to calculate $\bar{t}_{r}$.

If $v_{a}>0.15$ (air movement) $: \bar{t}_{r}=\left[\left(t_{g}+273\right)^{4}+\frac{1.1 \cdot 10^{8} v_{a}^{0.6}}{\varepsilon_{g} \cdot D^{0.4}}\left(t_{g}-t_{a}\right)\right]^{0.25}-273$

with $\bar{t}_{r}=$ mean radiant temperature $\left({ }^{\circ} \mathrm{C}\right)$

$t_{g}=$ globe temperature $\left({ }^{\circ} \mathrm{C}\right)$

$t_{a}=$ ambient temperature $\left({ }^{\circ} \mathrm{C}\right.$, shielded $)$

$v_{a}=$ air speed $\left(m s^{-1}\right)$

$D=$ globe diameter $($ standard $=0.15 \mathrm{~m}$ ) and

$\varepsilon_{g}=$ emission coefficient (matt black paint $=0.95$ )

If other equipment is used (Fig. 4) refer to ISO7726 for calculation of $\overline{t_{r}}$.

Sensor $\overline{t_{r}}$ range/accuracy: Comfort: $10-40^{\circ} \mathrm{C} / \pm 2 .^{\circ} \mathrm{C}$; Stress $-40-+150^{\circ} \mathrm{C} /$ between -40 and $+50^{\circ} \mathrm{C}: \pm 5^{\circ} \mathrm{C}$ above $+50^{\circ} \mathrm{C}$ : linear increase from $5^{\circ} \mathrm{C}$ to 13 at $150^{\circ} \mathrm{C}$; desirable accuracy comfort: $0.2^{\circ} \mathrm{C}$; stress: $5^{\circ} \mathrm{C}$. 
For measurement of plane radiant temperature, typically used in comfort assessment the accuracy required in the range of 0 to $50^{\circ} \mathrm{C}$ is $\pm 0.5^{\circ} \mathrm{C}$.

- Surface temperature ( $t_{s}$ ). Surface temperature is measured with special sensors (Fig. 3) that ensure a good contact with the surface while insulating the sensor from the environment, or with a non-contact infrared sensor (Fig. 4). With a contact sensor, the conduction between surface and sensor must be much higher than that from the sensor to the environment and sometimes conductive paste helps. Surfaces with very low conductivity however (e.g. wood, Styrofoam), may yield false values and here a non-contact infrared sensor is better. This is dependent on the emissivity/reflectivity of the surface, required to calculate the actual $t_{s}$. For most matt surfaces this is rather constant but shiny surfaces can act as a mirror, and the sensor may measure reflected radiation from other objects as well.

Sensor $t_{s}$ range/accuracy: Comfort: $0-50^{\circ} \mathrm{C} / \pm 1 .{ }^{\circ} \mathrm{C}$; Stress $-40-+120^{\circ} \mathrm{C} /$ between -10 and $+50^{\circ} \mathrm{C}: \pm 1^{\circ} \mathrm{C}$, below $-10^{\circ} \mathrm{C}$ and above $+50^{\circ} \mathrm{C}$ : linear increase from $1^{\circ} \mathrm{C}$ to $3.5^{\circ} \mathrm{C}$ and $4.5^{\circ} \mathrm{C}$ respectively to range limit; desirable accuracy comfort: $0.5^{\circ} \mathrm{C}$; stress: $0.5^{\circ} \mathrm{C}$

\section{Air humidity}

The amount of moisture present in the environmental air (the moisture concentration in $\mathrm{g}_{\mathrm{kg}} \mathrm{kg}^{-1}$, g. $\mathrm{m}^{-3}$ or vapour pressure in Pascal $[\mathrm{Pa}]$ ) determines whether moisture (sweat) in vapour form flows from the skin to the environment or vice versa. Often air humidity is expressed as relative humidity, i.e. the actual amount of moisture in the air compared to the maximum amount possible at that temperature:

$$
\begin{aligned}
R H & =100 \frac{p_{a}}{p_{a s}}(\%) \\
\text { with } p_{a} & =\text { ambient vapour pressure } \\
p_{a s} & =\text { saturated vapour pressure at ambient temperature }
\end{aligned}
$$

Relative humidity can be measured with hair hygrometers, but these have a very limited accuracy and react slowly. Electronic sensors (Fig. 5; capacitance sensors with relative humidity sensitive di-electricum; lithium chloride hygrometers) are available, but if exposed to extreme climates these tend to show a slow drift (over several days) and need regular recalibration. Very accurate, but costly, are dewpoint sensors that cool a smooth surface and detect the temperature at which condensation occurs, i.e. the dewpoint. The moisture concentration of the environment is then equal to the saturation vapour pressure at this dewpoint. 
The psychrometer (Fig. 5) is both accurate and affordable. It combines an ambient temperature sensor (dry bulb) and a temperature sensor with a wet cotton wick around it (wet bulb). Evaporation from the wet wick cools the thermometer, and lowers the wet bulb temperature relative to the dry bulb air temperature. The difference is used to calculate the relative humidity. Whirling the sensor in the air (a whirling hygrometer) or by having a fan suck air over it as in an Assman Psychrometer, helps the instrument attain stability. The Assman instrument also shields the sensors from thermal radiation (Fig. 5).

When no forced air movement is applied to the wick and the sensor is freely exposed to the environment, it is sensitive to air movement and radiation too and it is called a 'natural wet bulb thermometer'. This is part of a WBGT meter.

Relative humidity can be converted to vapour pressure as:

$$
p_{a}=\frac{R H}{100} \cdot p_{a s}=\frac{R H}{100} \cdot e^{\left[23.5613-\frac{4030.183}{t_{a}+235}\right]}
$$

If the dewpoint needs to be converted into vapour pressure, this is simply done using the last equation with $\mathrm{RH}=100 \%$ and the dewpoint temperature instead of $t_{a}$.

For the calculation of vapour pressure from the whirling hygrometer or psychrometer, i.e. from $t_{a}$ or dry bulb temperature $\left(t_{d b}\right)$ and aspirated wet bulb $\left(t_{w b}\right)$, the following equation is used:

$$
p_{a}=p_{a s}(\text { at wet bulb temperature })-667 \cdot\left(t_{a}-t_{w b}\right)=e^{\left[23.5613-\frac{4030.183}{t_{a}+235}\right]}-667 \cdot\left(t_{a}-t_{w b}\right) \quad(P a)(4)
$$

Other conversions can be found in ISO7726 (1998).

The moisture concentration or vapour pressure, not the relative humidity is the determining factor for skin evaporation. Saturated air that has a relative humidity of $100 \%$ can contain different amounts of moisture (equation 3), depending on its temperature. The higher the temperature, the higher the moisture content at equal relative humidities. When the air temperature is lower than the skin temperature, sweat will always be able to evaporate from the skin, even at $100 \%$ relative humidity as the skin's vapour pressure will be higher than that of the air.

Absolute humidity $p_{a}$ range/accuracy: Comfort: $500-3000 \mathrm{~Pa} / \pm 150 \mathrm{~Pa}$; Stress $500-6000 \mathrm{~Pa} / \pm$ $150 \mathrm{~Pa}$; accuracy to be guaranteed for a range of $\left|\bar{t}_{r}-t_{a}\right| \leq 10^{\circ} \mathrm{C}$ for comfort, and $\leq 20^{\circ} \mathrm{C}$ for stress. 
Air speed

The magnitude of air movement $\left(v_{a}\right)$ and its direction and turbulence affects both convective and evaporative heat losses, and heat exchange increases with increasing wind speed. In a cool environment the body cools faster in the presence of wind, whereas in an extremely hot, humid environment, it will heat up faster. In a very hot, but dry environment, it will promote dry heat transfer towards the body, but will also increase evaporative heat loss from the body.

Air speed can be measured using a vane or cup anemometer (Fig. 6) if the air movement is coming from a fixed direction and fluctuates only slowly. A hot wire anemometer is used if the wind is not unidirectional, or fluctuates fast, (Fig. 6). In some designs the heated wire is replaced by other heated shapes (sphere; Fig. 6). Air velocity can also be measured with a Kata -thermometer which has a very large, fluid reservoir (Fig. 6). It is first heated and then hung in the relevant location and allowed to cool to air temperature. The cooling speed measured by the drop of the fluid level in the stem over time is a measure for the air movement.

Sensor va : range/accuracy: Comfort: $0.05-1 \mathrm{~ms}^{-1} / \pm(0.05+0.05 \mathrm{va}) \mathrm{ms}^{-1}$; Stress $0.2-20 \mathrm{~ms}^{-1} / \pm$ $\left.\left(0.1+0.05 v_{a}\right) \mathrm{ms}^{-1}\right)$; response time $(90 \%$ of final value reached in this time): comfort $\leq 0.5 \mathrm{~s}$, desirable $\leq 0.2 \mathrm{~s}$ (for measurement of turbulence intensity).

\section{Measuring locations}

Spatial considerations: The exact location of thermal measurements should represent the actual worker's locations in the space, i.e. their workstations. If this is not practical, conditions should be measured over a grid of locations in the work place. The higher the thermal variations in space, the denser this grid will need to be. A grid width with 5 meters intervals should be sufficient for most situations. Apart from this horizontal distribution, it is also relevant to repeat measurements at different heights for each location: typically the worker's head, trunk and legs/feet height. For standing work: $1.7 \mathrm{~m}, 1.1 \mathrm{~m}$, and $0.1 \mathrm{~m}$. For sitting work: $1.1,0.6$ and $0.1 \mathrm{~m}$. In very homogeneous environments a measurement at abdomen level (1.1 $\mathrm{m}$ for standing, 0.6 for sitting) is sufficient.

Temporal considerations: Measurement at one point in time can be misleading. It may be important to investigate the climate profile for daily and seasonal patterns. Leaving equipment to $\log$ climate conditions for at least a day is the minimum. Using questionnaires to find out which are the problem times can save a lot of effort. 


\subsubsection{Personal parameters}

Some thermal comfort and stress assessment methods require information on clothing insulation and metabolic heat production.

\section{Clothing insulation}

Clothing resists heat and moisture transfer between skin and environment. This can protect against extreme heat and cold, but also hamper heat loss during physical effort. Clothing insulation $\left(\mathrm{m}^{2 \circ} \mathrm{CW}^{-1}\right.$ or in clo; $\left.1 \mathrm{clo}=0.155 \mathrm{~m}^{2 \circ} \mathrm{CW}^{-1}\right)$ is expressed either as total insulation ( $\mathrm{I} t$, includes surface air layer) or so-called 'intrinsic insulation' ( $I_{c l}$, clothing with enclosed air layers only). Values for clothing insulation ( $I_{\mathrm{T}}$ for clothing including surface air layer, or $I_{c l}$ for clothing only) and vapour resistance $\left(R_{e}\right)$ can be measured (Havenith, 1999, Havenith et al., 2002), but usually these are estimated from lists of insulations for numerous clothing ensembles. Extensive lists of clothing insulations as well as different methods for its estimation can be found in ISO 9920 (1995). Some examples are presented in Table 1.

Hardly any listings of clothing vapour resistance are available, but once insulation is known, vapour resistance can be estimated as:

$$
\begin{aligned}
R_{e} & =\frac{I_{t}}{0.0165 \cdot i_{m}} \\
\text { with } R_{e} & =\text { clothing vapour resistance }\left(\mathrm{Pa}^{\circ} \mathrm{CW}^{-1}\right) \\
I_{t} & =\text { clothing heat resistance }\left(\mathrm{m}^{2}{ }^{\circ} \mathrm{CW}^{-1}\right) \\
i_{m} & =\text { clothing permeability index (n.d.) } \\
0.0165 & =\text { Lewis constant }\left(0.0165^{\circ} \mathrm{C} . \mathrm{Pa}^{-1}\right)
\end{aligned}
$$

The value for $i_{m}$ can be estimated from Table 2 .

Clothing insulation and vapour resistance are affected by many factors: movement of the wearer, wind, wetting etc. For a more detailed description see Havenith et al. (1999, 2002), Holmér et al. (1999) and Nilsson et al. (2000). Table values for clothing insulation for most normal and warm weather clothing $\left(1,9\right.$ clo $>I_{\mathrm{T}}>1,2$ clo $)$ can be corrected: 


$$
\begin{aligned}
I_{T, \text { dynamic }} & =\text { correction factor } \cdot I_{T, \text { static }} \\
\text { correction factor } & =e^{\left(-0.281 \times\left(v_{a r}-0.15\right)+0.044 \times\left(v_{a r}-0.15\right)^{2}-0.492 \mathrm{w}+0.176 \mathrm{w}^{2}\right)} \\
\text { with } \quad I_{T, \text { static }} & =\text { clothing insulation obtained from tables } \\
w & =\text { walking speed; maximally } 1.2 \mathrm{~ms}^{-1} \\
& \text { if other movement, derive from metabolic rate as } \\
w & =0.0052 \times\left(\text { Metabolic rate }\left[\mathrm{Wm}^{-2}\right]-58\right) ; \text { limited to } \mathrm{w} \leq 0.7 \mathrm{~ms}^{-1} \\
v_{a r} & =\text { relative air speed; minimally } 0.15 \text {; maximally } 3 \mathrm{~ms}^{-1}
\end{aligned}
$$

For specialised, insulating cold weather clothing, which typically has low air permeability and where high wind speeds occur more frequently, the equation for the correction factor to be used is:

$$
\begin{aligned}
& \text { correction factor }=0.54 \cdot e^{\left(-0.15 v_{a}-0.22 w\right)} \cdot \mathrm{p}^{0.075}-0.06 \cdot \ln (p)+0.5 \\
& \qquad \begin{aligned}
& \text { with } \text { : } \\
& v_{a r}=\text { relative air speed; from } 0.4 \mathrm{~m} / \mathrm{s} \text { to } 18 \mathrm{~ms}^{-1} \\
& w=\text { walking speed }\left(\mathrm{ms}^{-1}\right) ; \text { from } 0 \text { to } 1.2 \mathrm{~ms}^{-1} \\
& p=\text { air permeability of outer fabric }\left(\mathrm{lm}^{-2} \mathrm{~s}^{-1}\right) ; \text { from } 1 \text { to } 1000 \mathrm{~lm}^{-2} \mathrm{~s}^{-1} \\
& \text { low: (e.g. coating or laminate) } 1 ; \text { medium } 50 ; \text { high (open weave) } 1000 \mathrm{~lm}^{-2} \mathrm{~s}^{-1}
\end{aligned}
\end{aligned}
$$

Here it is assumed that head and hands are covered with hood / hat and gloves; i.e. the body is totally covered.

For correction of vapour resistance the relations are slightly more complex. For most applications however, a reduction in vapour resistance equal to 1.3 times that in heat resistance (equation 8 or 9) is a good approximation. For more details see Havenith et al. $(1999,2002)$.

\section{Metabolic rate}

For most ergonomics applications the efficiency of external work (energy released outside the body) performed is close to zero. Only on cycle ergometers, or continuous walking upwards on stairs the efficiency climbs to significant values (maximum around 0.23). Hence almost all metabolic energy is released as heat in the body. It can be measured using indirect calorimetry (measuring oxygen uptake; ISO8996, 1990). Metabolic rates for a large number of activities can be estimated using tables describing activities, professions, postures etc. An overview is given in table 3 , with an example for a quite coarse classification in table 4; both taken from the extensive listings in ISO 8996 (1990) and from Spitzer et al. (1982). 


\subsection{Subjective methods}

For thermal environments subjective assessment methods have been developed suggesting scales to be used in questionnaires (ISO 10551, 1995). The subjective assessment is split in several categories for which the related questions are:

$\begin{array}{ll}\text { Category } & \text { Question } \\ \text { Perceptual: } & \text { How are you feeling (at this precise moment)? } \\ \text { Evaluation: } & \text { Do you find this .......? } \\ \text { Preference: } & \text { Would you prefer to be .....? } \\ \text { Acceptability: } & \text { Do you find this acceptable? } \\ \text { Tolerance: } & \text { Is it tolerable? }\end{array}$

The relevant scales to be used are shown in Table 5 to 8 .

Note that many factors other than workplace climate (e.g. stress, problems with management, general working conditions) affect dissatisfaction with the thermal environment. Wherever possible objective data should complement subjective assessments.

\section{Standard and Regulations}

The most relevant standards for this area are develop in the committees: ISO TC159/WG1 and CEN TC122/WG11:

\section{Basic standards:}

ISO 7726: 1998 (EN27726), Thermal environments - instruments and methods for measuring physical quantities.

ISO 8996: 1990 (EN28996), Ergonomics - determination of metabolic heat production.

ISO 9920 (EN9920): 1995, Ergonomics of the thermal environment - estimation of the thermal insulation and evaporative resistance of a clothing ensemble.

ISO 11399: 1995 (EN11399), Ergonomics of the thermal environment - principles and application of international standards.

ISO 13731 (prEN13202) Ergonomics of the thermal environment - vocabulary and symbols.

ISO 12894: 1993 (EN12894), Ergonomics of the thermal environment - medical supervision of individuals exposed to hot or cold environments. 
ISO 7730: 1994 (EN7730), Moderate thermal environments - determination of the PMV and PPD indices and specification of the conditions for thermal comfort.

ISO 7243: 1995 (EN7243) Hot environments - estimation of the heat stress on working man, based on the WBGT-index (wet bulb globe temperature).

ISO 7933: 1989 (EN12515), Hot environments - analytical determination and interpretation of thermal stress using calculation of required sweat rate.

ISO 9886: 1992 (EN9886), Evaluation of thermal strain by physiological measurements.

ISO 10551: 1995 (EN10551), Ergonomics of the thermal environment - assessment of the influence of the thermal environment using subjective judgement scales.

ISO TR 11079 (Technical Report): 1993 (ENV11079), Evaluation of cold environments determination of required clothing insulation, IREQ.

Risk of burns and cold injury

ISO/ NP 13732 Part 1. Ergonomics of the thermal environment - methods for the assessment of human responses to contact with surfaces. Part 1: Hot surfaces.

ISO CD 13732 Part 2. Ergonomics of the thermal environment - methods for the assessment of human responses to contact with surfaces. Part 2: Moderate surfaces.

ISO/NP 13732 Part 3. Ergonomics of the thermal environment - methods for the assessment of human responses to contact with surfaces. Part 3: Cold surfaces.

\section{Special applications}

ISO NP 14405: Ergonomics of the thermal environment - evaluation of the thermal environment in vehicles.

ISO NP 14415: Ergonomics of the thermal environment - application of international standards to the disabled, the aged and handicapped persons.

ISO NP 15743: Ergonomics of the thermal environment - working practices for cold indoor environments.

\section{Approximate training and application time}

Training in the use of instruments for thermal assessment should take around 2-4 hours depending on the user's background and should include recognising problems with the measurement instruments. A staged approach to thermal assessment can be used: first assessments are done by lay persons. If any thermal problems are indicated, more highly trained people become involved, and these again could call upon experts in critical cases (Malchaire, 2000). 
The application time is mainly determined by the number of locations, the type, amount and response times of the equipment (e.g. black globe: 20-30 min.) and by the expected variations in the climate. The more variable the climate, the longer the logging should be continued to catch average and worst case data. For seasonal effects, repeated measurements will be required.

\section{Reliability and validity}

Thermometers (mercury/alcohol thermometer, thermometer in black globe) will require calibration against a standard, but then are very stable and reliable. Humidity measurements based on wet bulb temperature are sensitive to pollution of the wick (replace regularly; use distilled water) and problems with the air ventilation rate. The sensor itself is a thermometer and thus reliable.

Electronic sensors (temperature, humidity, wind speed) need regular calibration of both sensor and electronic circuits combined. Electronic temperature sensors are usually quite stable, but electronic humidity measurements need regular checks and calibrations, especially when used in extremes.

Estimations of metabolic rate and of clothing insulation can show large errors $( \pm 10 \%)$. This should be considered when evaluating the outcome of the analyses.

\section{Tools needed}

A basic toolset should allow for the determination of the 4 climatic parameters: $t_{a}, \bar{t}_{r}, p_{a}$ (or $\mathrm{RH}$ ) and va. Hence it should consist of:

- an ambient temperature sensor: low cost: regular thermometer or electronic sensor, preferably shielded for radiation.

- a radiant temperature sensor: low cost: a black globe, medium/high cost: radiometer.

- humidity sensor: medium cost: whirling hygrometer, Assman psychrometer, Electronic RH sensor; high cost: dewpoint sensor.

- wind speed/air movement: medium cost: Kata-thermometer; hot wire anemometer and vane anemometer (unidirectional); high cost: heated sphere (multidirectional).

\section{Steps in method}

Steps that need to be taken for the objective assessment are:

- identify and select appropriate equipment to measure $t_{a}, \bar{t}_{r}, p_{a}$ (or $\left.\mathrm{RH}\right)$ and $v a$, considering range, accuracy and response time of apparatus and sensors,

- calibrate equipment,

- survey expected climate fluctuations in time (seasons, weather) and space within workspace by interviews with workers, 
- locate relevant workstations as measurement locations or define locations using a grid of the total workspace,

- define locations and measurement timing over day/seasons/weather conditions,

- measure and register climatic parameters at three heights (one height in highly uniform environments) at all locations,

- survey the work load (metabolic rate) and clothing (insulation) worn at the various workplaces,

- correct clothing insulation for movement and wind,

- take all data and use heat or cold stress, or comfort evaluation methods as described in following chapters.

\section{References}

Havenith, G. (1999). Heat Balance When Wearing Protective Clothing, Annals of Occupational Hygiene, 43(5) 289-296.

Havenith, G., Holmér, I., Den Hartog, E.A. \& Parsons, K.C. (1999). Clothing Evaporative Heat Resistance-Proposal for Improved Representation in Standards and Models, Annals of Occupational Hygiene, 43(5), 339-346.

Havenith, G., Holmér, I., \& Parsons, K. (2002). Personal factors in thermal comfort assessment: clothing properties and metabolic heat production, Energy and Buildings 34 (6)581-591.

Holmér, I., Nilsson, H., Havenith, G. \& Parsons, K.C. (1999). Clothing Convective Heat Exchange - Proposal for improved Prediction in Standards and Models, Annals of Occupational Hygiene, 43(5), 329-337.

ISO 10551 / EN10551 (1995). Ergonomics of the thermal environment - assessment of the influence of the thermal environment using subjective judgement scales. International Standardisation Organisation, Geneva

ISO 7726 / EN27726 (1998). Thermal environments - instruments and methods for measuring physical quantities. International Standardisation Organisation, Geneva.

ISO 8996 / EN28996 (1990). Ergonomics - determination of metabolic heat production. . International Standardisation Organisation, Geneva.

ISO 9920 / EN9920 (1995), Ergonomics of the thermal environment - estimation of the thermal insulation and evaporative resistance of a clothing ensemble. . International Standardisation Organisation, Geneva.

Malchaire, J. (2000). Strategy for the management of the thermal working conditions. Proceedings of the XIVth Triennial Congress of the International Ergonomics Association and 44th Annual Meeting of the Human Factors and Ergonomics Society, July 29-August 4, San 
Diego, California, USA. Published by the Human Factors and Ergonomics Society, Santa Monica, CA, US.A. [CD-Rom]

Nilsson, H., Anttonen, H. \& Holmér, I. (2000). New algorithms for prediction of wind effects on cold protective clothing; Ergonomics of Protective Clothing, Proceedings of Nokobetef 6, Stockholm, 17-20.

Spitzer, H., Hettinger, T., \& Kaminsky G. (1982). Tables for the energy usage in physical work (Tafeln für den Energieumsatz bei körperlicher Arbeit), Beuth Verlag, Berlin, ISBN 3-41036569-9 (in German). 
Fig. 1, The heat balance: the sum of all heat losses and gains of the body; left: in heat stress heat loss is lower than heat production, causing heat to be stored in the body (increase in body temperature); middle: in comfort loss and gain are balanced; right: in cold stress more is lost than produced, leading to body cooling. The size of the characters of the individual thermal heat exchange factors represents their importance in the three situations.

Fig. 2, Schematic representation of the pathways for heat loss from the body. $\mathrm{M}=$ metabolic heat production (reproduced with permission from Annals of Occupational Hygiene; Havenith, 1999).

Fig. 3, Example of shielded (radiation) ambient temperature sensor (right) and contact temperature sensor (left). This shielded sensor cannot be used with very high radiation levels, as with the single shield and the close proximity to the actual sensor and without ventilation of the space in the shield, the shield would heat up and affect the sensor through radiation.

Fig. 4, Three types of radiation measurements: bottom left: black globe with mercury thermometer in centre; bottom right: unidirectional sensor, using the temperature measurement of a reflective and an absorbing surface to calculate radiation levels; top: infrared radiation meter. This is a spot-meter with a small measuring angle, hence the visor to aim precisely at the correct spot.

Fig. 5, Humidity sensors; left: Assman psychrometer. The top cylinder contains a fan that draws air over the two thermometers. These can be seen in the left and right columns. The sensor heads are at the bottom, shielded against radiation by a double (ventilated) shield. One thermometer is covered with a muslin wick that is moistened and will cool the sensor (aspirated wet bulb temperature) in relation to relative humidity. The other sensor measures ambient (dry bulb) temperature (shielded for radiation). Middle: sling or whirling psychrometer; this works on the same principle of the Assman psychrometer, though air is drawn over the sensors by whirling it around in the air. There is no shielding against radiation, so in radiant environments this should be considered. Right: an electronic humidity sensor that can be read with an electronic display unit.

Fig. 6, Sensors for air movement/wind. Left: vane anemometer, to be used in unidirectional air movement; Second left: Kata-thermometer, to be freely hanging in air after pre-heating. Cooling speed is related to air speed; second from right: unidirectional hot wire anemometer: the actual wire protrudes at the top. It is extremely thin and is not really visible in this view. The shaft is used to protect the sensor when not in use; Right: spherical sensor, designed to be sensitive to multidirectional wind and with a fast response time. 
Table 1, sample values of clothing insulation values of various workwear (left) and daily wear (right) ensembles. $I_{\mathrm{cl}}=$ intrinsic clothing insulation (without adjacent surface air layer); $I_{\mathrm{T}}=$ total insulation (clothing + surface air layer). $\mathrm{Clo}=$ unit of insulation defined relative to the value of an American business suit $\left(1 \mathrm{clo}=0.155 \mathrm{~m}^{20} \mathrm{C} \mathrm{W}^{-1}\right)$

\begin{tabular}{|c|c|c|c|c|c|c|c|}
\hline Work clothing & & & $\begin{array}{c}I_{\mathrm{T}} \\
\mathrm{m}^{2 \circ} \mathrm{C} \mathrm{W}^{-1} \\
\end{array}$ & Daily wear clothing & & & $\begin{array}{c}I_{\mathrm{T}} \\
\mathrm{m}^{2 \circ} \mathrm{C} \mathrm{W}^{-1} \\
\end{array}$ \\
\hline Work clothing & & & $I_{\mathrm{T}}$ & Daily wear clothing & & & $I_{\mathrm{T}}$ \\
\hline & Clo & $\mathrm{m}^{2 \circ} \mathrm{CW}^{-1}$ & $\mathrm{~m}^{20} \mathrm{CW}^{-1}$ & & Clo & $\mathrm{n}^{20} \mathrm{CWW}^{-1}$ & $\mathrm{~m}^{2 \circ} \mathrm{CW}^{-1}$ \\
\hline Underpants, boiler suit, socks, shoes & 0.7 & 0.11 & 0.196 & $\begin{array}{l}\text { Panties, T-shirt, shorts, light socks, } \\
\text { sandals }\end{array}$ & 0.3 & 0.05 & 0.145 \\
\hline Underpants, shirt, trousers, socks, shoes & 0.75 & 0.115 & 0.200 & $\begin{array}{l}\text { Panties, petticoat, stockings, light dress } \\
\text { with sleeves, sandals }\end{array}$ & 0.45 & 0.07 & 0.162 \\
\hline $\begin{array}{l}\text { Underpants, shirt, boiler suit, socks, } \\
\text { Shoes }\end{array}$ & 0.8 & 0.125 & 0.209 & $\begin{array}{l}\text { Underpants, shirt with short sleeves, light } \\
\text { trousers, light socks, shoes }\end{array}$ & 0.5 & 0.08 & 0.171 \\
\hline $\begin{array}{l}\text { Underpants, shirt, trousers, jacket, socks, } \\
\text { Shoes }\end{array}$ & 0.85 & 0.135 & 0.218 & $\begin{array}{l}\text { Panties, stockings, shirt with short } \\
\text { sleeves, skirt, sandals }\end{array}$ & 0.55 & 0.085 & 0.175 \\
\hline $\begin{array}{l}\text { Underpants, shirt, trousers, smock, } \\
\text { socks, shoes }\end{array}$ & 0.9 & 0.14 & 0.222 & $\begin{array}{l}\text { Underpants, shirt, light-weight trousers, } \\
\text { socks, shoes }\end{array}$ & 0.6 & 0.095 & 0.183 \\
\hline $\begin{array}{l}\text { Underwear with short sleeves and legs, } \\
\text { shirt, trousers, jacket, socks, shoes }\end{array}$ & 1 & 0.155 & 0.235 & $\begin{array}{l}\text { Panties, petticoat, stockings, dress, } \\
\text { shoes }\end{array}$ & 0.7 & 0.105 & 0.192 \\
\hline $\begin{array}{l}\text { Underwear with short legs and sleeves, } \\
\text { shirt, trousers, boiler suit, socks, shoes }\end{array}$ & 1.1 & 0.17 & 0.248 & Underwear, shirt, trousers, socks, shoes & 0.7 & 0.11 & 0.196 \\
\hline $\begin{array}{l}\text { Underwear with long legs and sleeves, } \\
\text { thermo jacket, socks, shoes }\end{array}$ & 1.2 & 0.185 & 0.262 & $\begin{array}{l}\text { Underwear, track suit (sweater and } \\
\text { trousers), long socks, runners }\end{array}$ & 0.75 & 0.115 & 0.200 \\
\hline $\begin{array}{l}\text { Underwear with short sleeves and legs, } \\
\text { shirt, trousers, jacket, thermo jacket, } \\
\text { socks, shoes }\end{array}$ & 1.25 & 0.19 & 0.266 & $\begin{array}{l}\text { Panties, petticoat, shirt, skirt, thick knee- } \\
\text { socks, shoes }\end{array}$ & 0.8 & 0.12 & 0.205 \\
\hline $\begin{array}{l}\text { Underwear with short sleeves and legs, } \\
\text { boiler suit, thermo jacket and trousers, } \\
\text { socks, shoes }\end{array}$ & 1.4 & 0.22 & 0.293 & $\begin{array}{l}\text { Panties, shirt, skirt, round neck sweater, } \\
\text { thick knee-socks, shoes }\end{array}$ & 0.9 & 0.14 & 0.222 \\
\hline $\begin{array}{l}\text { Underwear with short sleeves and legs, } \\
\text { shirt, trousers, jacket, thermo jacket and } \\
\text { trousers, socks, shoes }\end{array}$ & 1.55 & 0.225 & 0.297 & $\begin{array}{l}\text { Underpants, singlet with short sleeves, } \\
\text { shirt, trousers, V-neck sweater, socks, } \\
\text { shoes }\end{array}$ & 0.95 & 0.145 & 0.226 \\
\hline $\begin{array}{l}\text { Underwear with short sleeves and legs, } \\
\text { shirt, trousers, jacket, heavy quilted outer } \\
\text { jacket and overalls, socks, shoes }\end{array}$ & 1.85 & 0.285 & 0.352 & $\begin{array}{l}\text { Panties, shirt, trousers, jacket, socks, } \\
\text { shoes }\end{array}$ & 1 & 0.155 & 0.235 \\
\hline $\begin{array}{l}\text { Underwear with short sleeves and legs, } \\
\text { shirt, trousers, jacket, heavy quilted outer } \\
\text { jacket and overalls, socks, shoes, cap, } \\
\text { Gloves }\end{array}$ & 2 & 0.31 & 0.375 & Panties, stockings, shirt, skirt, vest, jacket & 1 & 0.155 & 0.235 \\
\hline $\begin{array}{l}\text { Underwear with long sleeves and legs, } \\
\text { thermo jacket and trousers, outer } \\
\text { thermo jacket and trousers, socks, shoes }\end{array}$ & 2.2 & 0.34 & 0.403 & $\begin{array}{l}\text { Panties, stockings, blouse, long skirt, } \\
\text { jacket, shoes }\end{array}$ & 1.1 & 0.17 & 0.248 \\
\hline $\begin{array}{l}\text { Underwear with long sleeves and legs, } \\
\text { thermo jacket and trousers, parka with } \\
\text { heavy quilting, overalls with heavy } \\
\text { quilting, socks, shoes, cap, gloves }\end{array}$ & 2.55 & 0.395 & 0.454 & $\begin{array}{l}\text { Underwear, singlet with short sleeves, } \\
\text { shirt, trousers, jacket, socks, shoes }\end{array}$ & 1.1 & 0.17 & 0.248 \\
\hline & & & & $\begin{array}{l}\text { Underwear, singlet with short sleeves, } \\
\text { shirt trousers, vest, jacket, socks, shoes }\end{array}$ & 1.15 & 0.18 & 0.257 \\
\hline & & & & $\begin{array}{l}\text { Underwear with long sleeves and legs, } \\
\text { shirt, trousers, V-neck sweater, jacket, } \\
\text { socks, shoes }\end{array}$ & 1.3 & 0.2 & 0.275 \\
\hline & & & & $\begin{array}{l}\text { Underwear with short sleeves and legs, } \\
\text { shirt, trousers, vest, jacket, coat, socks, } \\
\text { shoes }\end{array}$ & 1.5 & 0.23 & 0.302 \\
\hline
\end{tabular}


Table 2, Example data for the estimation of the static clothing permeability index $\left(\mathrm{i}_{\mathrm{m}}\right)$ using description of the clothing type (Havenith et al., 1999). Difference between cold and heat values represent the effect of condensation at the inner clothing surface. Intermediate values can be interpolated as $\mathrm{i}_{\mathrm{m}}=\left(\alpha \mathrm{i}_{\mathrm{m} 15}+(1-\alpha) \mathrm{i}_{\mathrm{m} 30}\right)$ with $\alpha=(30$-air temperature) $/ 15$.

\begin{tabular}{|c|c|c|}
\hline \multirow{2}{*}{ Clothing description } & \multicolumn{2}{|c|}{ Estimated $i_{m}$ static } \\
\hline & In the cold $\left(<15^{\circ} \mathrm{C}\right)$ & In the heat $\left(>30^{\circ} \mathrm{C}\right)$ \\
\hline Nude & \multicolumn{2}{|c|}{0.5} \\
\hline $\begin{array}{c}\text { Normal, permeable clothing, regardless of number of } \\
\text { layers }\end{array}$ & \multicolumn{2}{|c|}{0.38} \\
\hline As 1, with tightly woven jacket & \multicolumn{2}{|c|}{0.34} \\
\hline As 1 , with coated jacket OR trousers & \multicolumn{2}{|c|}{0.31} \\
\hline As 1 , with two piece semipermeable overgarment & 0.17 & 0.15 \\
\hline As 1 , with one piece semipermeable overgarment & 0.14 & 0.13 \\
\hline As 1, with two piece impermeable overgarment & 0.12 & 0.07 \\
\hline As 1, with one piece impermeable overgarment & 0.1 & 0.06 \\
\hline $\begin{array}{l}\text { As } 1 \text {, with one piece impermeable overgarment, covered } \\
\text { head except face, gloves, openings sealed (e.g. immersion } \\
\text { suit }\end{array}$ & 0.06 & 0.02 \\
\hline $\begin{array}{l}\text { Completely encapsulating suit, all openings sealed, no } \\
\text { skin exposed }\end{array}$ & 0.05 & 0.0 \\
\hline
\end{tabular}


Table 3: Six methods for estimating metabolic heat production (ISO 8996)

\begin{tabular}{|c|c|c|c|}
\hline Level & Method & Accuracy & $\begin{array}{l}\text { Inspection of the work } \\
\text { place. }\end{array}$ \\
\hline \multirow[t]{2}{*}{ I } & $\begin{array}{l}\text { A-Classification } \\
\text { according to kind of } \\
\text { activity }\end{array}$ & $\begin{array}{l}\text { Rough information where } \\
\text { the risk of error is very } \\
\text { great }\end{array}$ & Not necessary \\
\hline & $\begin{array}{l}\mathrm{B}-\text { Classification } \\
\text { according to occupation }\end{array}$ & & $\begin{array}{l}\text { Information on } \\
\text { technical equipment, } \\
\text { work organization }\end{array}$ \\
\hline \multirow[t]{3}{*}{ II } & $\begin{array}{l}\text { A - Use of tables of group } \\
\text { assessment }\end{array}$ & $\begin{array}{l}\text { High error risk: accuracy } \pm \\
15 \%\end{array}$ & Time study necessary \\
\hline & $\begin{array}{l}\text { B- Use of estimation tables } \\
\text { for specific activities }\end{array}$ & & \\
\hline & $\begin{array}{l}\text { C- Use of heart rate under } \\
\text { defined conditions }\end{array}$ & & Not necessary \\
\hline III & Measurement & $\begin{array}{l}\text { Risk of errors within the } \\
\text { limits of the accuracy of the } \\
\text { measurement and of the } \\
\text { time study: accuracy } \pm 15 \%\end{array}$ & Time study necessary \\
\hline
\end{tabular}


Table 4 - Classification of metabolic rate based on general work description

\begin{tabular}{|c|c|c|c|}
\hline \multirow[t]{2}{*}{ Class } & \multicolumn{2}{|c|}{$\begin{array}{l}\text { Value to be used } \\
\text { for calculation of } \\
\text { mean metabolic } \\
\text { rate } \\
\end{array}$} & \multirow[t]{2}{*}{ Examples } \\
\hline & $\left(\mathrm{W} / \mathrm{m}^{2}\right)$ & $\mathrm{W}$ & \\
\hline $\begin{array}{c}0 \\
\text { Resting } \\
\end{array}$ & 65 & 115 & Resting \\
\hline$\frac{1}{\text { Low metabolic rate }}$ & 100 & 180 & $\begin{array}{l}\text { Sitting at ease: light manual work (writing, typing, } \\
\text { drawing, sewing, book-keeping); hand and arm work } \\
\text { (small bench tools, inspection, assembly or sorting of } \\
\text { light materials); arm and } \\
\text { leg work (driving vehicle in normal conditions, } \\
\text { operating foot switch or pedal). } \\
\text { Standing: drilling (small parts); milling machine (small } \\
\text { parts); coil winding; small armature winding; machining } \\
\text { with low power tools; casual walking (speed up to 3,5 } \\
\mathrm{km} / \mathrm{h} \text { ). }\end{array}$ \\
\hline $\begin{array}{l}2 \\
\text { Moderate } \\
\text { metabolic rate }\end{array}$ & 165 & 295 & $\begin{array}{l}\text { Sustained hand and arm work (hammering in nails, } \\
\text { filing); arm and leg work (off-road operation of lorries, } \\
\text { tractors or construction equipment); arm and trunk work } \\
\text { (work with pneumatic } \\
\text { hammer, tractor assembly, plastering, intermittent } \\
\text { handling of moderately heavy material, weeding, } \\
\text { hoeing, picking fruits or vegetables, pushing or pulling } \\
\text { light-weight carts or wheelbarrows, walking at a speed } \\
\text { of } 3,5 \mathrm{~km} / \mathrm{h} \text { to } 5,5 \mathrm{~km} / \mathrm{h} \text {, forging). }\end{array}$ \\
\hline $\begin{array}{c}3 \\
\text { High metabolic rate }\end{array}$ & 230 & 415 & $\begin{array}{l}\text { Intense arm and trunk work; carrying heavy material; } \\
\text { shovelling; sledgehammer work; sawing; planing or } \\
\text { chiselling hard wood; hand mowing; digging; walking at } \\
\text { a speed of } 5,5 \mathrm{~km} / \mathrm{h} \text { to } 7 \mathrm{~km} / \mathrm{h} \text {. } \\
\text { Pushing or pulling heavily loaded hand carts or } \\
\text { wheelbarrows; chipping castings; concrete block laying. }\end{array}$ \\
\hline $\begin{array}{l}\quad 4 \\
\text { Very high } \\
\text { metabolic rate }\end{array}$ & 290 & 520 & $\begin{array}{l}\text { Very intense activity at fast to maximum pace; working } \\
\text { with an axe; intense shovelling or digging; climbing } \\
\text { stairs, ramp or ladder; walking quickly with small steps: } \\
\text { running; walking at a speed greater than } 7 \mathrm{~km} / \mathrm{h} \text {. }\end{array}$ \\
\hline
\end{tabular}


Table 5 - Examples of the wording of subjective judgement scales on thermal conditions: Scale of perceptual judgements on personal thermal state (after the question "How are you feeling now?")

\begin{tabular}{|c|c|c|c|c|}
\hline Poles & Degrees & English & French & Spanish \\
\hline \multirow{5}{*}{ HOT } & $(+4)$ & very hot & $\begin{array}{l}\text { extrêmement } \\
\text { chaud }\end{array}$ & calor excesivo \\
\hline & +3 & hot & très chaud & mucho calor \\
\hline & +2 & warm & chaud & calor \\
\hline & +1 & slightly warm & $\begin{array}{l}\text { légèrement } \\
\text { chaud }\end{array}$ & algo de calor \\
\hline & 0 & neutral & ni chaud ni froid & ni calor ni frio \\
\hline \multicolumn{5}{|l|}{ INDIFFERENCE } \\
\hline \multirow{4}{*}{ COLD } & -1 & slightly cool & légèrement froid & algo de frio \\
\hline & -2 & cool & Froid & frio \\
\hline & -3 & cold & Très froid & mucho frio \\
\hline & $(-4)$ & very cold & $\begin{array}{l}\text { extrêmement } \\
\text { froid }\end{array}$ & frio excesivo \\
\hline \multicolumn{2}{|c|}{ Common introductory term(s) } & I'm feeling/I'm & J'ai.... & Tengo...... \\
\hline \multicolumn{5}{|c|}{$\begin{array}{l}\text { NOTE: The central tendency of the perceptual judgements obtained by applying one of the } \\
\text { above-mentioned scales yields an observed mean vote which can be compared with the } \\
\text { Predicted Mean Vote PMV index) determined according to ISO } 7730 \text {. }\end{array}$} \\
\hline
\end{tabular}


Table 6, Scale of evaluative judgements on personal thermal state (after the question "Do you find this (....?)

\begin{tabular}{|l|l|l|}
\hline Pole & Degree & Wording of degrees \\
\hline \multirow{4}{*}{ DISCOMFORT } & 0 & comfortable \\
\cline { 2 - 3 } & 1 & slightly uncomfortable \\
\cline { 2 - 3 } & 2 & uncomfortable \\
\cline { 2 - 3 } & 3 & very uncomfortable \\
\cline { 2 - 3 } & 4 & I tremely uncomfortable \\
\hline Common introductory terms & I find i... \\
\hline NOTE By summing up the judgements which express discomfort, one obtains an \\
observed percentage of dissatisfied people, which can be compared with the Predicted \\
Percentage of Dissatisfied (PPD index) determined according to ISO 7730.
\end{tabular}

Table 7 - Thermal preference scale; (after the instruction "Please state how you would prefer to be now")

\begin{tabular}{|c|c|c|c|}
\hline \multirow{2}{*}{ Poles } & Degrees & $\begin{array}{c}\text { Wording of } \\
\text { degrees for } \\
\text { 7-degree scale }\end{array}$ & $\begin{array}{c}\text { Equivalent for } \\
\text { 3-degree scale }\end{array}$ \\
\hline \multirow{3}{*}{ WARMER } & +3 & much warmer & \multirow{2}{*}{ Warmer } \\
\cline { 2 - 3 } & +2 & warmer & a little warmer \\
\cline { 2 - 3 } & +1 & neither warmer nor cooler \\
\hline \multirow{2}{*}{ COOLER } & -1 & slightly cooler & \multirow{2}{*}{ Cooler } \\
\cline { 2 - 3 } & -2 & cooler & \multicolumn{2}{|c|}{ much cooler } \\
\cline { 2 - 3 } & -3 & \multicolumn{2}{|c|}{ I would prefer to be } \\
\hline \multicolumn{2}{|c|}{ Common introductory terms } & \multicolumn{2}{|c}{} \\
\hline
\end{tabular}


Table 8 - Personal acceptability statement form

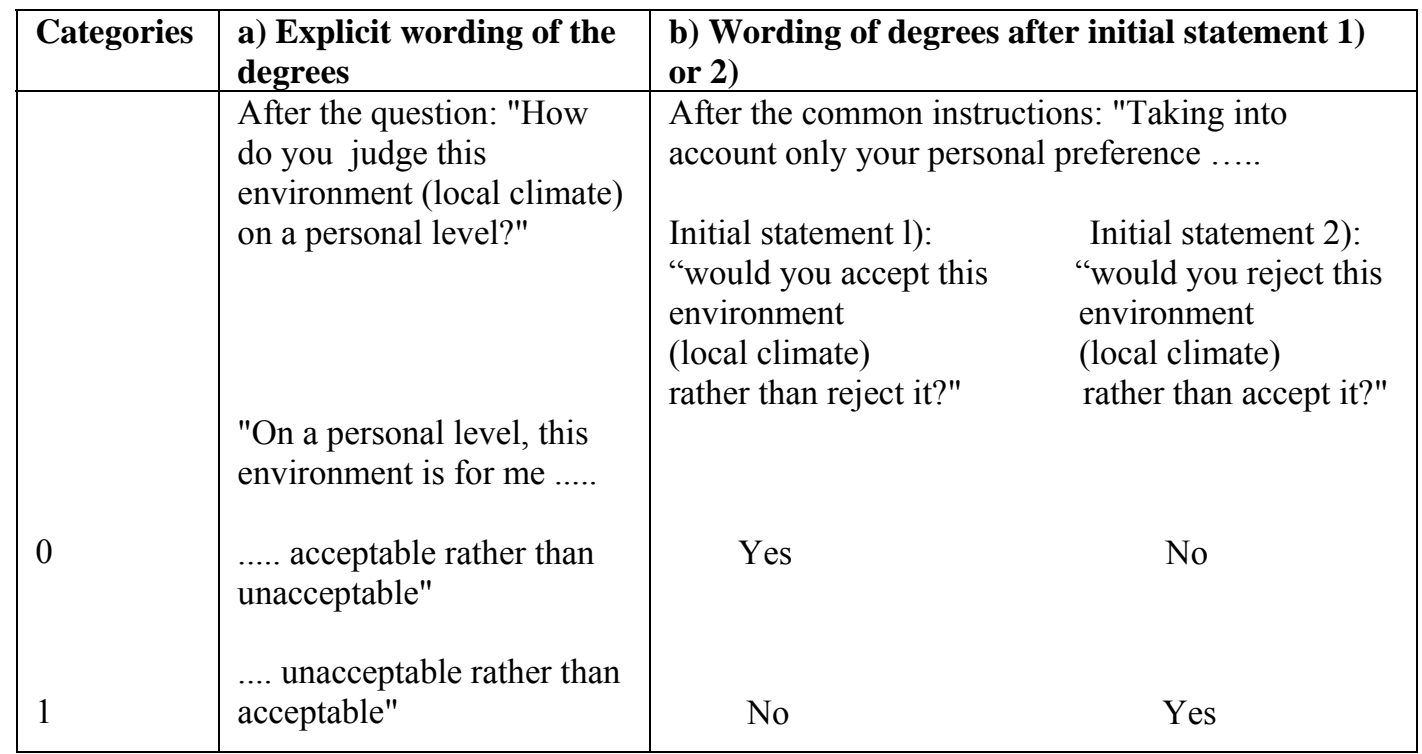

Instead of using a two-category statement form, personal acceptability may be expressed on a continuous scale, such as the following:

\begin{tabular}{|c|c|c|c|}
\hline $\begin{array}{l}\text { clearly } \\
\text { acceptable }\end{array}$ & just acceptable & just unacceptable & clearly unacceptable \\
\hline
\end{tabular}

The preliminary instructions would be as follows [after the question "How do you judge this environment (local climate) on a personal level?" or after instruction "Taking *into account only your personal preference"]-. "Please mark the appropriate place on the scale to express your acceptance of the environment (local climate). Do not mark the middle of the scale, but express either acceptance or unacceptance". 


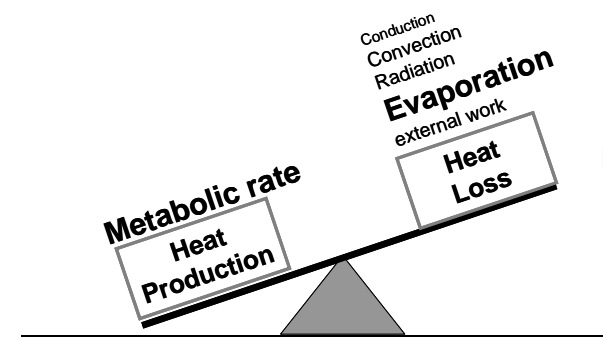

Heat Stress

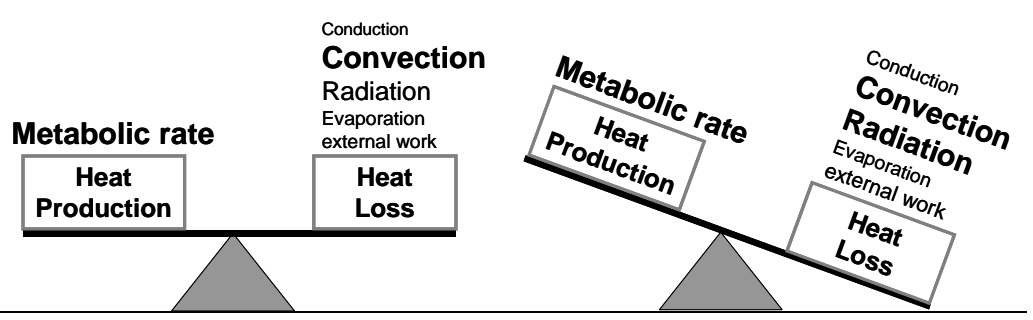

Comfort
Cold Stress

Drawing: George Havenith $(\subset$

Fig 1

\section{Avenues of Heat Exchange}

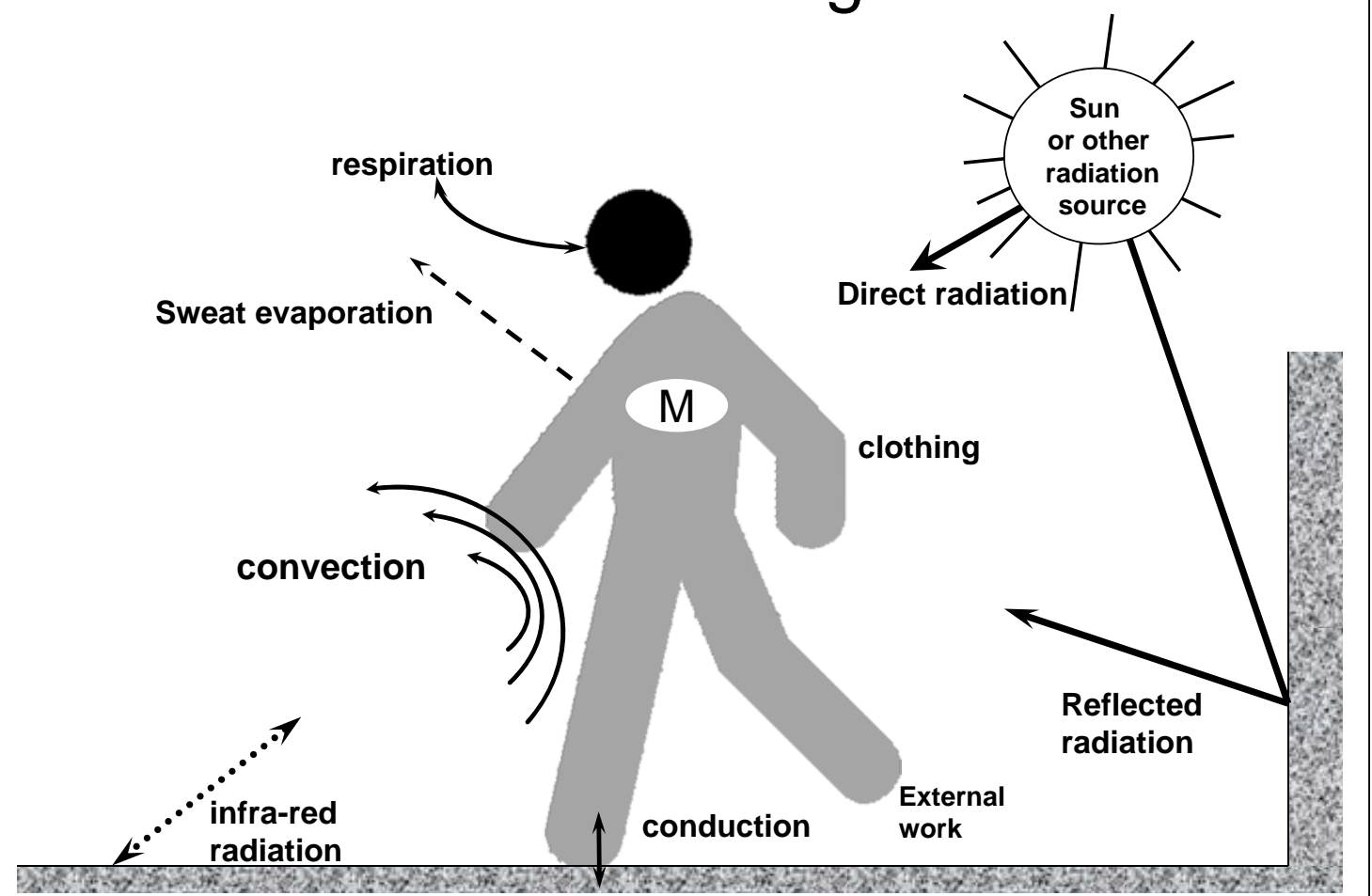

Fig

Drawing: George Havenith (c) 


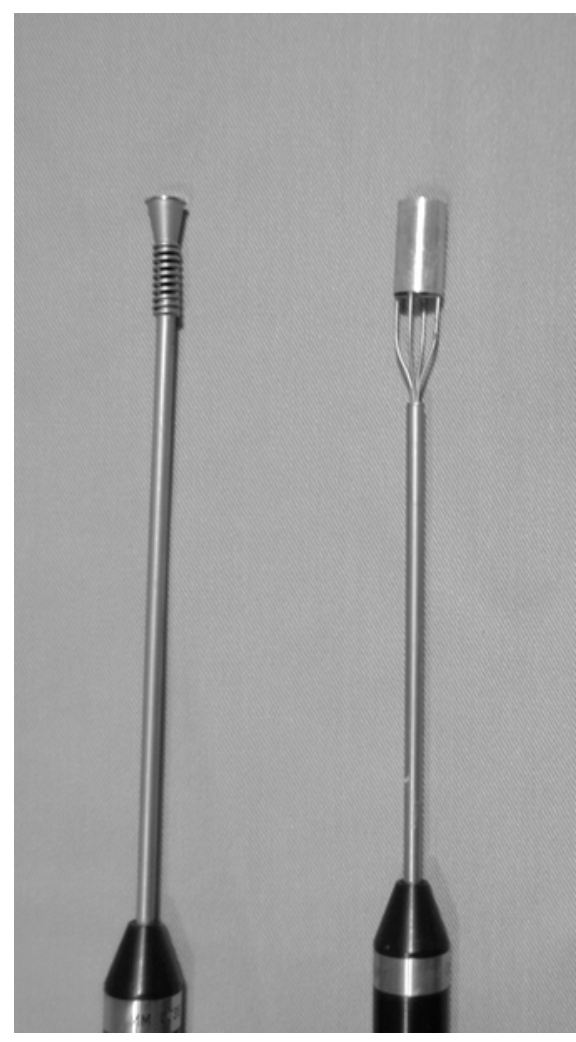

Fig 3

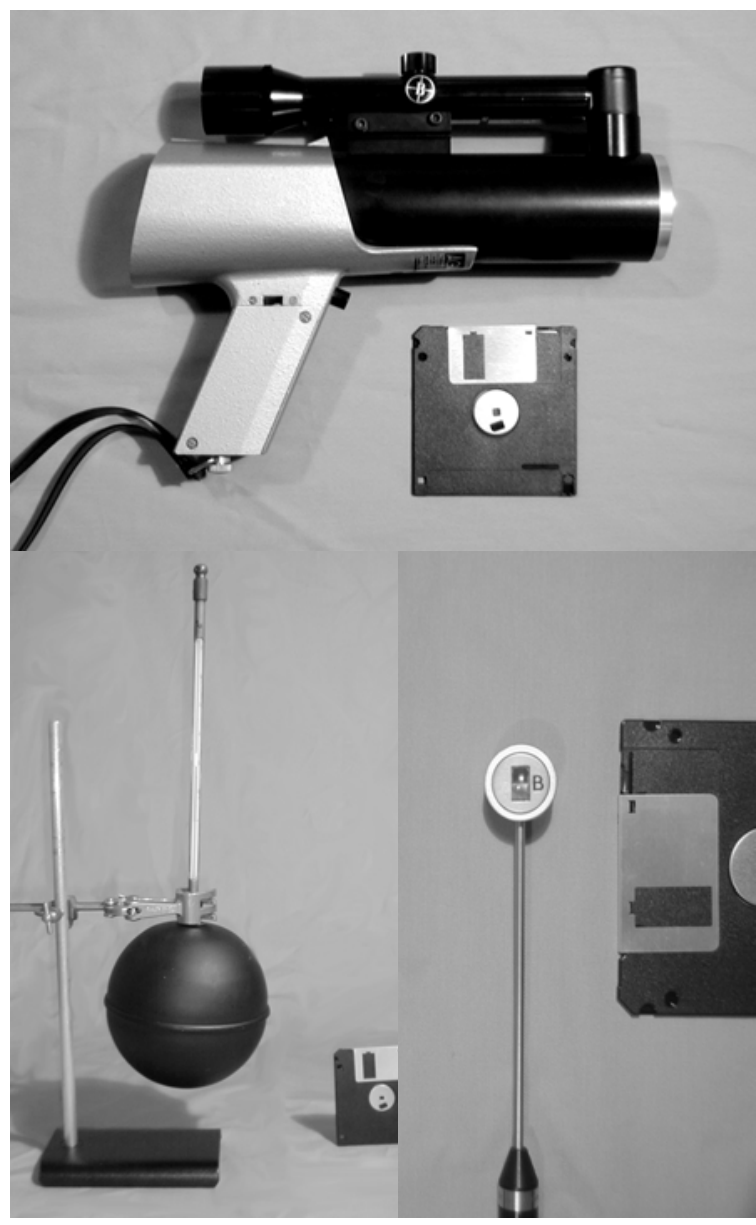

Fig 4

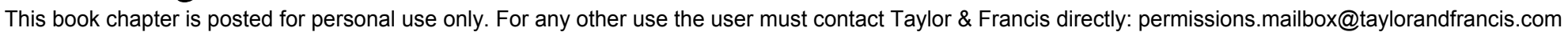


Fig 5
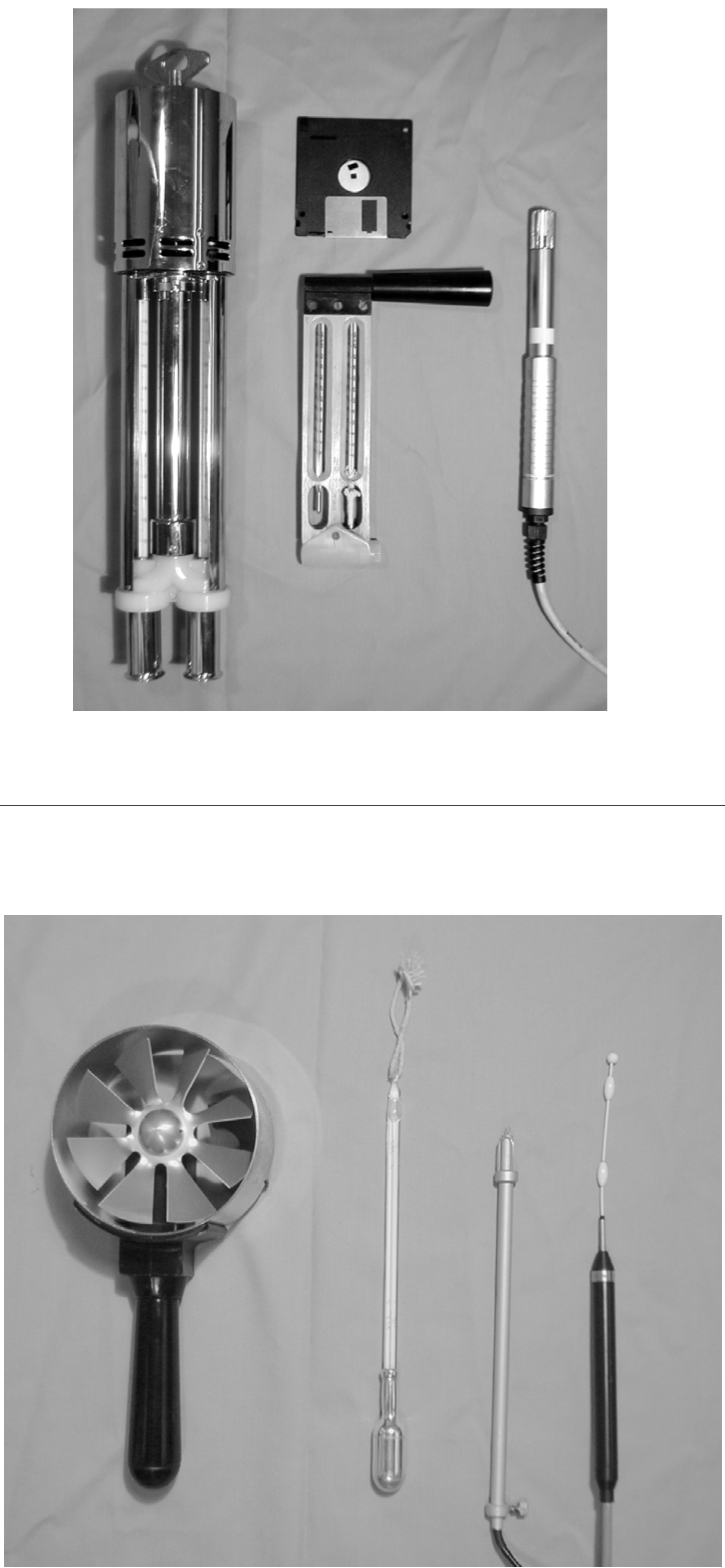

Fig 6

This book chapter is posted for personal use only. For any other use the user must contact Taylor \& Francis directly: permissions.mailbox@taylorandfrancis.com 